\title{
Uygulama Öğretmenlerinin Görev, Rol ve Eğitim Gereksinimlerine İlişkin Algıları
}

\author{
Mentors' Perceptions Regarding to Their Duties, Roles and \\ Educational Needs
}

\author{
Meltem YALIN UÇAR*
}

• Geliş Tarihi: 09.01.2015 • Kabul Tarihi: 03.02.2016 • Yayın Tarihi: 31.01.2017

\begin{abstract}
ÖZ: $\mathrm{Bu}$ araştırma, uygulama öğretmenlerinin görev, rol ve sorumluluklarının neler olduğunu ve yine katılımcı görüşlerine göre uygulama öğretmenliğine ilişkin eğitim gereksinimi ihtiyacını belirlemeyi amaçlamıştır. Çalışma nitel araştırma yöntemi ile gerçekleştirilmiştir. Ülkenin farklı bölgelerinde ve yedi ayrı şehirde görev yapmakta olan 78 uygulama öğretmeni ve öğretmenlik uygulamalarından sorumlu 22 okul yöneticisi, olasılık temelli küme örnekleme yöntemi ile belirlenmiş ve toplam 100 katılımcıdan elde edilen veriler, betimsel analiz yöntemi ile çözümlenmiştir. Betimsel çözümleme yoluyla ulaşılan temalar, uygulama öğretmenlerinin öğretmen adayına ilişkin sorumluluklarının duyuşsal faktörlere bağlı olduğunu, rollerinin iletişim, görevlerinin ise kendi akademik yeterliliklerini sağlamak olduğunu göstermektedir. Ayrıca uygulama öğretmenliğine ilişkin bir eğitim gereksinimi içinde olunduğu anlaşılmaktadır.
\end{abstract}

Anahtar sözcükler: Uygulama öğretmeni (mentör), öğretmen adayı, uygulama okulu yöneticisi, görev, rol, sorumluluk.

\begin{abstract}
This study aims at identifying mentor teachers' views on duties, roles and responsibilities as well as educational needs concerning mentorship. The study adopted a qualitative research methodology. 78 mentor and 22 school administrator responsible for mentorship, who how been working in various regions and 7 different districts of the country, were selected through probability based cluster sampling and the data gathered from a total of 100 participants were analyzed using descriptive analysis. The attained themes show that mentors' responsibilities regarding prospective teachers depend on affective factors, their roles are communication and that mentors' duties are obtaining their academic proficiencies. Besides, findings indicate that there is a need for mentor training.
\end{abstract}

Keywords: Mentor, teacher candidate, practice school administrator, duty, role, responsibility.

\section{GíRiş}

Uluslararası literatürde, bir bilenin bilmeyene yaptığı rehberlik, "mentörlük” ülkemizde ise "uygulama öğretmenliği" kavramı ile nitelendirilmektedir. Mentör kavramı, ilk kez Yunan mitolojisinde kullanılmıştır. Sözü edilen dönemlerde, Odysseia destanının kahramanı Odysseus'un yakın dostu olan ve küçük oğlu Telemachus'u savaş dönemlerinde emanet ettiği Mentör kişidir. Böylece Mentör, aslında onun kılığına bürünmüş Odysseus'un koruyucu tanrısı bilge Athena; yarı insan, yarı tanrı, yarı kadın yarı erkek, inanılabilir fakat ulaşılamaz olan kişidir. Mitolojiden sonra, mentörlük kavramı, özel isim olarak kullanılmaktan çıkmış ve öncelikle eğitim alanına girerek okul yaşantısı yeni olan öğretmen adayına akademik, idari ve sosyal konularda yol gösteren, onun yeni ortama uyumuna yardımcı olan ve oryantasyonunu sağlayan kişi olarak kullanılmıştır (Baltaş, 2004). Literatürde, mentörlük ile ilgili birçok tanımın yer aldığı görülmektedir. Bu tanımların, genellikle öğretmen adayı ile uygulama öğretmeni arasında süregiden sosyal, entelektüel ve insancıl bir ilişki temeline oturtulduğu (Lentz ve Allen, 2007) ve bu ilişkinin de amaç ve yolun birleşimi (Daloz, 1983) olduğu söylenmektedir. Uluslararası literatürde, alanında deneyimli olan meslek erbabının, mesleğe henüz başlayan ya da başlayacak olan meslektaşına yaptığı mesleki rehberliğe mentörlük, ülkemizde ise uygulama öğretmenliği denilmektedir. Uygulama öğretmeni, uygulama okulunda görevli, öğretmenlik

\footnotetext{
*Yrd. Doç. Dr., Adnan Menderes Üniversitesi, Eğitim Fakültesi, Aydın, Türkiye, myalinuc@gmail.com
} 
meslek bilgisine sahip, alanında deneyimli öğretmenler arasından seçilen, öğretmen adayına öğretmenlik mesleğinin gerektirdiği davranışları kazanmasında rehberlik ve danışmanlık yapan sınıf veya ders öğretmeni (MEB, 2014) olarak tanımlanmıştır. Uygulama öğretmenliği, sistemde görev yapmakta olan bir öğretmenin, kendi öğrencilerine olan öğretmenlik sorumluluklarının yanında, öğretmen adayına ilişkin üstlenilen sorumluluğun yerine getirilmesiyle ilgilidir. $O$ halde uygulama öğretmenliği, deneyimli olan öğretmen ile deneyimsiz öğretmen adayı arasında kurulan iliş̧iden oluşmaktadır. Bu ilişki iki ayrı açıdan ele alınmaktadır: Birincisi, geleneksel uygulama öğretmenliğine dayalı olarak oluşur ve ustasından öğrenen çırak modeli söz konusudur. İkincisinde ise çağdaş bir yaklaşım vardır ve süreçte, düzenli hiyerarşik yaşantılar ile bu yaşantılar arasında kariyer geliştirmeye odaklı uygulama öğretmenliği ilişkisinden söz edilir. Her iki modelde, sözü edilen ilişkinin iki temel işlev ve bu işlevlere bağlı olarak geliştirilen görev, rol ve sorumlulukları vardır. Bunlardan birincisi kariyer/enstrumantal, ikincisi ise psikososyal işlevdir. Enstrümantal/kariyer işlevi, ilişkinin dişsal değerini yansıtır ki bu da öğretmen adaylarının, mentörlerin (uygulama öğretmenlerinin) bilgisinden, ilişkilerinden, desteğinden ve rehberliğinden yararlanma olarak nitelendirilir ve Türkiye de mentörlük sistemi (uygulama ögretmenliği) de aşağıda yer alan maddeler çerçevesinde bu yaklaşıma göre yapılandırılmıştır. Öğretmenlik uygulamaları yönergesine göre bir uygulama öğretmeni (mentör):

1. Uygulama öğretim elamanı ve uygulama okulu koordinatörü ile iş birliği yaparak öğretmen adaylarının, uygulama çalışmaları kapsamındaki etkinlikleri hazırlar.

2. Uygulama programının gerektirdiği etkinliklerin yürütülmesini sağlar, uygulama etkinliklerinin başarılı bir biçimde yerine getirilmesi için öğretmen adayına rehberlik eder, bu etkinlikleri izler ve denetler.

3. Uygulama sonunda öğretmen adayının uygulama çalışmalarını değerlendirir, uygulama okulu koordinatörüne teslim eder (YÖK, 1998; MEB, 2014).

Psikososyal işlev de ise, karşılıklı ilişkinin niteliğine bağlı olarak bireyler arası diyalog, işbirliğine dayalı eleştirel düşünme, planlama, yansıtma ve değerlendirmeye dayalı mentörlüğün içsel değeri oluşturulmaktadır (Galbraith ve Cohen, 1995). Bu içsel değer, uygulama öğretmeniöğretmen adayı ilişkinin niteliğini belirlemektedir. Bu nedenle mentörlük tesadüfen oluşmaz ve aynı şekilde yararları da bir anda ortaya çıkmaz. Çünkü mentörlük, insanlar arası psikolojik gelişimi, kariyeri veya eğitimsel gelişimi, sosyalleşme işlevlerini bu ilişkide birleştiren, farklı uzmanlıkları olan bireylerin arasında oluşan karışık, interaktif (Carmin 1988'den Akt. Brom, 1996) bir süreci içermektedir. Hangi model söz konusu olursa olsun bu süreçte karş1lıkl1lık ve tutarlılık parametreleri sağlanabildiği ölçüde saygı, profesyonellik, meslektaşlık ve başarı elde edilmektedir (Brom, 1996). Bu nedenle uygulama öğretmenine, tek bir rol biçmektense, onu; dinleyen, destek veren, danışman, rehber, model, arkadaş, gelişime yardımcı kaynak kişi (Bell, 1997) gibi değişik roller üstelen biri olarak nitelemek daha doğru olacaktır. Söz konusu rol ve sorumluluk kapsamında bir uygulama öğretmeni, derslerini örnek bir şekilde yürütür, sınıfını gözlem yaparak yönetir ve teknolojiyi kullanmada konusunda modeldir. Ayrıca değerlendirme sürecinde, fikir analizi yapan, öğretim programı ve öğretme etkinliklerini planlayan, kaynakları bir araya getiren, etkili davranış yönetimi becerileri konusunda donanımlı olan, öğretmen adayının bilgi analizi anlayışını geliştiren, öğretmede yansıtıcı bir yaklaşım gösteren, kendini değerlendiren, yeniliklere açık olan ve bu görüşleri kullanabilendir (Moir ve Gless, 2004). Sözü edilen birçok değişkenin en belirleyici olanları, uygulama öğretmeninin bilgi ve anlayışının yanında mesleki becerileri ile tutum ve değerleri önem kazanmaktadır (Fish, 1995). Böylece görev, rol ve sorumluluk kavramlarının, uygulama öğretmeninin bilgi ve anlayışı perspektifinde önemli bir yere sahip olduğunu söylemek mümkündür. Çünkü uygulama öğretmenlerinin rehberliğe (mentörlüğe) bilgi ve tutumları açısından hazır olmaları, öğretmenlik uygulaması dersinin etkililiği bağlamında ön koşuldur. Öğretmenin öğrenilmesi, bir dizi karmaşık 
davranışları, yeterli ve beceri düzeyi yüksek yetiştiriciler ile öğretmen adaylarını gerektirmektedir (Maynard ve Furlog, 1994). Bu gereklilikten yola çıkılarak söz konusu süreçte bilimsel bir bilgi temelini oluşturmak amacıyla yapılan ve öğretmenlik uygulamaları sürecini farklı değişkenlerin etkisiyle ele alan araştırmalar mevcuttur. Bu araştırmalardan bazılarının sonuçları (Baştürk 2010; Karaca ve Aral, 2011; Sazak, 2003; Yapıcı ve Yapıc1, 2004; Yalın Uçar, 2008b; Yıldız, 2002) uygulama öğretmenlerinden kaynaklanan problemler ile ilgilidir. Çünkü Uygulama öğretmenlerinin rolleri, açık ve net bir biçimde tanımlanmadığı ve öğretmenlik uygulaması için belirlenen hedeflerin yetersizliği nedeniyle öğretmen adayları uygulama sürecinde çeşitli sorunlarla karşılaşmaktadırlar (Gökçe, Demirhan, 2005b). Söz konusu sorunların giderilmesiyle ilgili olarak ayrıca, Fakülte-Okul İşbirliği (1988) kitapçığında, uygulama sürecinde yer alan tüm değişkenlerin, zaman içerisinde değişime ve gelişime açik bir şekilde bilimsel araştırmalar yolu ile geliştirilebileceği vurgusu yapılmıştır. Böylece konuyla ilgili tüm araştırmacıların, araştırmalar ve projeler yoluyla veri toplama, verileri analiz etme ve önerilerde bulunmalarıyla uygulama öğretmenlerine yardımcı olunabileceği (Gökçe, Demirhan, 2005a) düşünülmektedir.

Yukarıda sözü edilen gerekçeler, uygulama öğretmenlerinin (mentörlerin), öğretmenlik uygulamaları sürecinde kendi görev, rol ve sorumluluklarını nasıl betimlediklerini ortaya koymalarını gerekli kılmıştır. $\mathrm{Bu}$ amaçla, öğretmenlik uygulamalarının gerçekleştirildiği ortamdaki uygulayıcıların perspektifinden, uygulama öğretmenlerinin görev, rol ve sorumluluklarının neler olduğu ve nasıl olması gerektiğinin anlaşılması, öğretmenlik uygulamalarının amacına ulaşması bakımından önemli görülmektedir. Ayrıca, uygulama öğretmenlerinin söz konusu görev, rol ve sorumluluklarla ilgili eğitim gereksinimi içinde olunup olunmadığı bu araştırmanın amacı içerisinde yer almaktadır.

\section{YÖNTEM}

Araştırma, nitel yöntem ile gerçekleştirilmiş olup "bütüncül tek durum” deseni kullanılmıştır. Durum çalışmaları, kendi gerçek yaşam çerçevesi içinde yer alan olgular arasında kesin hatların bulunmadığı ve birden fazla kanıt ve veri kaynağının mevcut olduğu durumlarda kullanılan görgül bir araştırma yöntemidir. Kısaca, araştırmacının kontrol edemediği bir olgu ya da olayı derinliğine incelemesine olanak veren bir araştırma yöntemidir (Yıldırım ve Şimşek, 2005). "Bütüncül" kavramı, holistik bir yaklaşımın karşıllğıdır. Birbiri ile ilişkili birimlerin bir arada değerlendirilmesini gerektirmektedir. Çünkü her bir birim, bütünden bağımsız değildir. "Tek Durum" kavramı ise, araştırma konusunun, tek bir analiz birimi (bir birey, bir kurum, bir program vb.) olarak değerlendirilmesi ile ilgilidir. Bu araştırmada, öğretmenlik uygulamaları sürecinin gerçekleştirildiği "uygulama okulu” boyutu kendi içinde bütünlük oluşturan bir eğitim sürecidir ve bu süreçten sorumlu olan okul yöneticileri ve uygulama öğretmenleri, öğretmen adayının uygulama boyutundan sorumlu olan birbirleri ile ilişkili olarak yine öğretmen adayının, niteliğini belirlemeleri açısından bütüncül ve tek durum olma nedenini oluşturmaktadır. $\mathrm{Bu}$ yöntem ile öğretmen adaylarının ve okul yöneticilerinin, bazı olayları, nesneleri, davranışları, algıları nasıl yorumladıkları ve anlamlandırdıkları anlaşılmaya çalışılmıştır. Özellikle yorumlar, rakamlara ya da normlara indirgenmeden (Glense,2013) araştırma raporunun tanımlayıcı olmasına dikkat edilmiştir.

\subsection{Veri Kaynakları}

Araştırmanın veri kaynakları, olasılık temelli örnekleme içinde yer alan ve hem nitel hem de nicel araştırma sürecinde yaygın olarak kullanılan küme örnekleme yöntemi (Yıldırım ve Şimşek, 2005) ile belirlenmiştir. Araştırmanın katılımcıları, devlet okullarında görev yapmakta olan ve uygulama öğretmeni olarak görevlendirilen sinıf öğretmenleri ve uygulama okulu yöneticilerinden oluşmuştur. Araştırma grubunu belirleme süreci, Türkiye'nin farklı bölgelerinde, özellikle eğitim fakültesi sınıf öğretmenliği bölümü bulunan illerden rastlantısal olarak birer şehrin belirlenmesi ile başlamıştır. Bu şehirlerdeki uygulama okulları (ilkokul), 
şehrin sosyo-ekonomik olarak farklılık gösteren üst, orta ve alt düzeyde yer alan semt ve mahallelerden seçilmiştir. Bu sedlerde yer alan birer uygulama okulu seçkisiz olarak belirlenmiştir. Bu okullarda görev yapmakta olan sınıf öğretmenlerinden, uygulama öğretmenliği görevini en az bir kez üstlenmiş olan uygulama öğretmenleri (mentörler) ve öğretmenlik uygulamasından sorumlu müdür ya da müdür yardımcıları ile görüşmeler gerçekleştirilmiştir. Uygulama öğretmenlerinin mesleki deneyimleri sadece Ağrı ilinde iki ile beş yıl arasında değişmekte iken, Ankara, 12 ile 24 yıl; Mersin, 6 ile 20 yıl; Aydın, 10 ile 24 yıl; Sinop, 5 ile 14 yıl; Bolu, 6 ile 20 yıl ve Bursa da, 10 ile 25 yıl; arasında yer almaktadır. Bu durumda mesleki deneyimin, iç Anadolu ve batı ilerine göre azaldığını söylemek mümkündür. Uygulama öğretmenlerinin, 54'ü Sınıf Öğretmenliği Bölümü (30’u iki yıllık ön lisans, 24'ü lisans) mezunu iken, 16'1 Fen-Edebiyat Fakültesi, dördü Ziraat Fakültesi, İkisi İlahiyat Fakültesi diğer iki uygulama öğretmeni de Psikoloji Bölümü mezunudurlar. Yine araştırmanın veri kaynaklarından olan okul yöneticilerinin tamamının mesleki deneyimleri 8 ile 25 arasında değişmektedir. Yurt dışında profesyonel olarak gerçekleştirilen "uygulama öğretmenliği”"nde en az beş yıl mesleki deneyim koşulu aranmaktadır bu nedenle araştırmada, katılımcı deneyimine ayrı bir özen gösterilmiştir. $\mathrm{Bu}$ araştırmadan elde edilen veriler, mesleki deneyim ve mezun olunan lisans programı değişkenine göre sınıflandırılmadığı için, katılımcıların mezun olduğu bilim dalları ve mesleki deneyimleri ayrı bir tablo olarak belirtilmemiştir.

Araştırmanın verileri, ülkenin farklı kesimlerinde bulunan yedi ayrı şehirdeki üçer uygulama okulu olmak üzere toplam 21 uygulama okulundan elde edilmiştir. Araştırmanın veri kaynakları, tablo 1'de verilmektedir.

Tablo 1: Katılımcıların illere göre dağılımı

\begin{tabular}{lccc}
\hline \multicolumn{1}{c}{ Şehirler } & $\begin{array}{c}\text { Uygulama } \\
\text { Öğretmenleri }\end{array}$ & $\begin{array}{c}\text { Uygulama Okulu } \\
\text { Yöneticileri }\end{array}$ & Toplam \\
\hline $\begin{array}{l}\text { Ankara (3 ilköğretim } \\
\text { okulu) }\end{array}$ & 12 & 3 & 15 \\
$\begin{array}{l}\text { Mersin (3 ilköğretim } \\
\text { okulu) }\end{array}$ & 11 & 2 & 13 \\
Aydın (3 ilköğretim okulu) & 14 & 4 & 18 \\
Ağrı (3 ilköğretim okulu) & 9 & 3 & 12 \\
Sinop (3 ilköğretim okulu) & 10 & 3 & 13 \\
$\begin{array}{l}\text { Bolu (3 ilköğretim okulu) } \\
\text { Bursa (3 ilköğretim okulu) }\end{array}$ & 10 & 3 & 13 \\
\hline $\begin{array}{l}\text { Toplam (21 ilköğretim } \\
\text { okulu) }\end{array}$ & 12 & 4 & 16 \\
\hline
\end{tabular}

Tablo 1'den anlaşılacağı üzere, ülkenin doğu, bat1, güney, kuzey ve orta kesimlerinde yer alan illerden Ankara, Mersin, Aydın, Ağrı, Sinop, Bolu ve Bursa olmak üzere toplam yedi şehir örneklem grubuna dahil edilmiştir. Yetmiş sekiz uygulama öğretmeni ile yüz yüze grup, 22 okul yöneticisi ile de yüz yüze bireysel görüşmeler yapılmıştır. Görüşmeler, uygulama öğretmenleri ile üçerli, beşerli ve altışarlı gruplar halinde gerçekleştirilmiştir. Böylece araştırma kapsamında, 100 katılımcının araştırma problemine ilişkin görüşleri elde edilmiştir.

\subsection{Veri Toplama Aracı}

Araştırmanın odak grup ve bireysel görüşmelerde kullanılan açık uçlu yarı-yapılandırılmış görüşme soruları; alan taraması, en az beş yıllık öğretmenlik deneyimi olan ve uygulama öğretmenliği görevini üstlenmiş mentör ve uygulamalardan sorumlu öğretim elemanları ile yapılan görüşmeler sonrasında oluşturulmuştur. Görüşme formunda yer alan birinci soru, "öğretmenlik uygulamaları sürecinde, öğretmen adayının yetiştirilmesi ile ilgili olarak 
sorumluluklarınız hakkındaki düşünceleriniz nelerdir?", ikincisi “öğretmenlik uygulamaları sürecinde, öğretmen adayının yetiştirilmesi ile ilgili olarak görev ve rolleriniz hakkında neler düşünüyorsunuz?", üçüncü soru "sizce uygulama öğretmeni (mentör) nasıl olunur?"şeklinde olmuştur. Ayrıca her bir soruyu açımlayan sonda sorulara yer verilmiştir. Öğretmenlik uygulamaları süreci, uygulama öğretmenleri ve okul yöneticileri için ortak bir konudur. Ancak, her ilkokulun öğretmenlik uygulamalarından sorumlu okul müdürü ve bir müdür yardımcısı bulunmaktadır. $\mathrm{Bu}$ nedenle zamanı uygun olan okul yöneticisi ile bireysel görüşmeler yapılmıştır. Odak grup görüşmeleri de, bireysel görüşme yönteminin üzerine kurgulanmış (Krueger ve Casey, 2000) bir yöntemdir. Bu araştırmada her iki görüşme şekli, aynı amaç için kullanılmıştır.

\subsection{Verilerin Çözümlenmesi}

Araştırma sürecinden elde edilen veriler, katılımcılara yöneltilen sorular dikkate alınarak temalandırılmıştır. Öncelikle, betimsel analiz için araştırma sorusu ve bu soruyu açımlayan sonda sorulardan bir çerçeve oluşturulmuştur. Bu çerçeve kapsamında veriler temalaştırılarak organize edilmiştir. İkinci aşamada, veriler anlamlı ve mantıklı olarak biraraya getirilmiş ve alıntıların seçimine olanak sağlanmıştır. Böylece katılımcılardan seçilen alıntı ifadelerinin açık, anlaşılır ve tutarlılı olmasına, deneyimlere uygunluğuna, ifadenin inandırıcıllğına, önemine ve araştırma konusu ile birebir ilişkili olmasına dikkat edilmiştir. Üçüncü aşamada organize edilen veriler, tanımlanmış ve araştırma raporunun bulgular bölümünde doğrudan alıntılara yer verilmiştir. Alıntılara yer verilirken, araştırmanın katılımcıları aşağıda yer alan tablo 2 de, yapılan kısaltmalar aracılığı ile ifade edilmiş̧tir. Söz konusu kısaltmalar, örneğin ülkenin batı kesiminde yer alan ildeki üç okuldan birincisi için B1, ikinci okul için B2 üçüncü okul için ise B3 kısaltması yapılmıştır. "B" harfi, batı da yer alan şehri, "1" birinci okulu, "md" ise okul müdürünü tanımlamaktadır. Dördüncü aşamada ise tanımlanan bulgular açıklanarak yorumlanmıştır.

Tablo 2: Araştırmanın veri kaynaklarına ilişkin yapılan kısaltmalar

\begin{tabular}{|c|c|c|c|}
\hline Bölgeler & Okul Yöneticileri & Bölgeler & Uygulama Öğretmenleri \\
\hline \multirow{3}{*}{$\begin{array}{l}\text { Ülkenin } \\
\text { Orta } \\
\text { Kesimi }\end{array}$} & O1md.: 1. Okulun Yöneticisi & \multirow{3}{*}{$\begin{array}{l}\text { Ülkenin } \\
\text { Orta } \\
\text { Kesimi }\end{array}$} & O1: 1. Okulun Uygulama Öğretmenleri \\
\hline & O2md.: 2. Okulun Yöneticisi & & O2: 2. Okulun Uygulama Öğretmenleri \\
\hline & O3md.: 3. Okulun Yöneticisi & & O3: 3. Okulun Uygulama Öğretmenleri \\
\hline \multirow{3}{*}{$\begin{array}{l}\text { Ülkenin } \\
\text { Doğu } \\
\text { Kesimi }\end{array}$} & D1md. : 1. Okul Yöneticisi & \multirow{3}{*}{$\begin{array}{l}\text { Ülkenin } \\
\text { Doğu } \\
\text { Kesimi }\end{array}$} & D1: 1. Okulun Uygulama Öğretmenleri \\
\hline & D2md. : 2. Okul Yöneticisi & & D2: 2. Okulun Uygulama Öğretmenleri \\
\hline & D3md. : 3. Okul Yöneticisi & & D3: 3. Okulun Uygulama Öğretmenleri \\
\hline \multirow{3}{*}{$\begin{array}{l}\text { Ülkenin } \\
\text { Kuzey } \\
\text { Kesimi }\end{array}$} & K1md. : 1. Okul Yöneticisi & \multirow{3}{*}{$\begin{array}{l}\text { Ülkenin } \\
\text { Kuzey } \\
\text { Kesimi }\end{array}$} & K1: 1. Okulun Uygulama Öğretmenleri \\
\hline & K2md. : 2. Okul Yöneticisi & & K2: 2. Okulun Uygulama Öğretmenleri \\
\hline & K3md. : 3. Okul Yöneticisi & & K3: 3. Okulun Uygulama Öğretmenleri \\
\hline \multirow{3}{*}{$\begin{array}{l}\text { Ülkenin } \\
\text { Batı } \\
\text { Kesimi }\end{array}$} & B1md. : 1. Okul Yöneticisi & \multirow{3}{*}{$\begin{array}{l}\text { Ülkenin } \\
\text { Batı } \\
\text { Kesimi }\end{array}$} & B1: 1. Okulun Uygulama Öğretmenleri \\
\hline & B2md. : 2. Okul Yöneticisi & & B2: 2. Okulun Uygulama Öğretmenleri \\
\hline & B3md. : 3. Okul Yöneticisi & & B3: 3. Okulun Uygulama Öğretmenleri \\
\hline \multirow{3}{*}{$\begin{array}{l}\text { Ülkenin } \\
\text { Güney } \\
\text { Kesimi }\end{array}$} & G1md. : 1. Okul Yöneticisi & \multirow{3}{*}{$\begin{array}{l}\text { Ülkenin } \\
\text { Güney } \\
\text { Kesimi }\end{array}$} & G1: 1. Okulun Uygulama Öğretmenleri \\
\hline & G2md. : 2. Okul Yöneticisi & & G2: 2. Okulun Uygulama Öğretmenleri \\
\hline & G3md. : 3. Okul Yöneticisi & & G3: 3. Okulun Uygulama Öğretmenleri \\
\hline
\end{tabular}

2.3.1 Iç ve Dış Geçerlilik: Bu çalışmayı gerçekleştirebilmek için öncelikle Milli Eğitim Bakanlığı'ndan araştırma izni alınmıştır. Alınan izin belgesi ile belirlenen yedi ayrı şehre araştırmacı bizzat giderek il Milli Eğitim Müdürlükleri’nden araştırma iznini yeniden yapılandırmış ve ilgili şube müdürlüklerinden öğretmenlik uygulaması yapılan okullar tespit edilmiştir. Araştırmacı bir sonraki gün, uygulama okulu listesinden seçkisiz olarak belirlediği bir ilköğretim okulu müdürlüğüne ulaşarak araştırmayı gerçekleştirebilmek için okul müdürlüğünden iznini yenilemiştir. Genellikle aynı gün, bazen de bir gün sonraya sarkan görüşmeler, uygulama okullarında gerçekleşmiştir. $\mathrm{Bu}$ görüşmeler, okul yöneticileriyle 
makamlarında araştırmacı ile yalnız iken, uygulama öğretmenleri ile de boş bir sınıf, müdür odası, laboratuvar veya spor salonunda üçerli, beşerli ve altışarlı grup görüşmeleri yapılmıştır (başkaları tarafindan rahatsız edilmeyecek, görüşmeyi kesintiye uğratmayacak mekânlarda görüşmeler yapılmaya çalışılmıştır). Görüşmeler sürecinde, araştırmacı söylenilenlere dahil olmamış ve görüşmeleri yönlendirilmemiştir. Araştırma sürecinde yüz yüze yapılan görüşmelerde söylenilenler, araştırmacı tarafından anında yazılarak ayrıntılı ve derinlemesine veriler elde edilmiştir. Her görüşmede, sürecin akışına göre belirlenen bir noktada söylenilenlerin yazılı aktarımının, görüşmeciler tarafından teyit edilmesi sağlanmıştır. Her ildeki araştırma süreci en az beş günde, araştırmacı tarafından tek başına yürütülmüştür.

Yine verilerden elde edilen temalara, bir başka alan uzmanı tarafından hem ulaşı1mış hem de teyit ettirilmiştir. Böylece izlenen süreç ayrıntılandırılarak iç geçerlik sağlanmaya çalışılmıştır. Ayrıca, iç geçerliliği sağlayan ve önemli değişkenlerden olan araştırma bulguları, elde edilen veriler doğrultusundadır ve yine araştırmanın doğasına uygun ve anlamlıdır. Araştırmanın alt problemlerine bağlı olarak elde edilen verilerin, betimlenerek temalaştırılmış olması, araştırmanın bulgularını tutarlı ve anlamlı kılmaktadır. Araştırma bulgularının kavramsal çerçeve ile olan tutarlılığına önem verilmiştir. Süreçte araştırmacının rolü açıklanmaya çalışılarak olay ve olguların anlaşılabilirliliği artırılmaya çalışılmış ve elde edilen veriler, görüşme sırasında ve sonunda görüşmecilere teyit ettirilerek katılımcılar tarafından gerçekçi bulunması sağlanmıştır. Ayrıca sonuç ve öneriler bölümünün, araştırmanın verileri ile tutarlılık göstermesine önem verilmiştir. Dış Geçerlilik: Araştırmanın örneklemi, görüşme ortamları ve süreç özellikleri farklı araştırmalar ile karşılaştırma yapabilmeyi sağlayacak şekilde ayrıntılı olarak tanımlanmıştır. Yine araştırmanın kavramsal çerçevesi doğrultusunda oluşturulan örneklem, elde edilen veriler ve ulaşılan bulgular, bu araştırmasının doğası ile sınırlandırılmış olduğu bilgisi araştırmanın sonuç ve öneriler bölümünde yer almaktadır

2.3.2 İç ve Dış Güvenirlilik: Çalışmanın sonuçlarının araştırmacıdan bağımsız olduğunu gösteren değişkenleri sağlayabilmek için, elde edilen veriler, betimsel olarak doğrudan sunulmuş daha sonra araştırmacının yorumuna yer verilmiştir. Veri analizi ise yine kavramsal çerçeveye bağl1 olarak gerçekleştirilmiştir. Dış Güvenirlilik: Araştırmanın, ülkenin farklı coğrafi bölgelerinde gerçekleştirilmiş olması ve örneklemin, araştırma durumuna olan uygunluğu dış güvenirliği sağlayan değişkenler arasında yer almaktadır. Her bir il ve buna bağlı olarak üç ayrı uygulama okulunda yapılan araştırma toplam 35 gün içerisinde gerçekleşmiştir.

Araştırmacının süreçteki rolü, iç geçerlilik başlığı altında ele alınmıştır. Veri kaynakları tanımlanmıştır. Yine elde edilen verilerin ortamları betimlenmiştir. Son olarak veri toplama aracı ve veri analizi süreci detaylandırılmaya çalışılmıştır.

\section{BULGULAR}

Betimsel analiz sonucunda elde edilen temalar, araştırmanın alt problemleri dikkate alınarak üst ve alt temalar aracılığı ile aktarılmıştır. Araştırmanın verileri, ilkokulların sosyoekonomik farklılıkları dikkate alınarak elde edilmiştir. Fakat verilerin analizi sonucunda elde edilen benzer bulgular nedeni ile ilkokulların sosyo-ekonomik durumu dikkate alınmaksızın katılımcı görüşlerine yer verilmiştir. Betimsel analiz sonucunda elde edilen temalar Tablo 3 te yer almaktadır.

Tablo 3. Araştırmanın verilerinden elde edilen temalar 


\begin{tabular}{|c|c|c|c|}
\hline Alt Problemler & Üst Tema & Tema & Alt Tema \\
\hline \multirow{2}{*}{$\begin{array}{l}\text { 1.Uygulama Ö̆ğretmenliği } \\
\text { Sorumluluğu }\end{array}$} & Duyuşsal Faktörler & --- & 1.Manevi Doyum 2.Vicdan \\
\hline & & $\begin{array}{c}\text { Sorumluluk Almayı Sağlayan } \\
\text { Faktörler }\end{array}$ & $\begin{array}{l}\text { 1.Farkındalık Eğitimi } \\
\text { 2.Geniş Zaman }\end{array}$ \\
\hline $\begin{array}{l}\text { 2.Uygulama Ö̈̆retmenlerinin } \\
\text { Görev ve Rolleri }\end{array}$ & Görev ve Rol & $\begin{array}{l}\text { 1.Akademik Yeterlilik } \\
\text { 2. İletişim }\end{array}$ & --- \\
\hline $\begin{array}{l}\text { 3.Uygulama Öğretmenliğine } \\
\text { İlişkin Ĕ̈itim Gereksinimi }\end{array}$ & Eğitim İhtiyacı & $\begin{array}{l}\text { 1.Akdemik Yeterlilik 2.İletişim } \\
\text { 3. Eğitim Süresi 4. Aktif Öğrenme }\end{array}$ & $\begin{array}{ll}--- \\
\end{array}$ \\
\hline Toplam & 3 Adet & 7 Adet & 4 Adet \\
\hline
\end{tabular}

\subsection{Birinci Alt Probleme İlişkin Bulgular: Uygulama Öğretmenliği Sorumluluğu}

Araştırmadan elde edilen bulgular, mentörlerin (uygulama öğretmenlerinin), öğretmen adayına ilişkin yasal bir sorumluluklarının olmadığını göstermektedir. Öğretmen adayına ilişkin herhangi bir sorumlulukları olmadığı halde bu süreci, duyuşsal faktörlere bağlı olarak yürüttükleri anlaşılmaktadır. Ancak, sorumluluk almayı sağlayan koşullar, farkındalık eğitimi ve geniş zaman dilimine yayılan uygulama süreci ile sağlanır ise öğretmenlik uygulamaları sürecine ilişkin sorumluluk bilincinin oluşturulabileceği anlaşılmaktadır.

\section{Duyuşsal Faktörler (Üst Tema):}

Öğretmenlik uygulamaları süreci, duyuşsal faktörlere bağlı olarak yürütülmektedir. $\mathrm{Bu}$ duyuşsal faktörler, manevi doyum ve vicdan alt temaları olarak betimlenmiştir. $\mathrm{Bu}$ betimlemelerden uygulama öğretmenlerinin, manevi doyum ve vicdanları gereği öğretmen adaylarının sorumluluklarını üstlendikleri anlaşılmaktadır. Bu durum, uygulama öğretmeni ile öğretmen adayı arasında profesyonel bir ilişkinin olmadığını göstermektedir. Öğretmen adaylarının yetiştirilmesi ile ilgili sorumluluğun manevi doyuma yani yürek gücüne dayalı olarak gerçekleştirildiğini söyleyen bir grup uygulama öğretmeni (B4 ve B5'ten 9 öğretmen), "Öğretmen adayını yetiştirme sorumluğumuzun dayanağı ülke ve vatandaş sorumluluğudur" demişlerdir. Aynı ilin farklı uygulama okulunda görev yapmakta olan uygulama öğretmenleri de sağlanan manevi doyumun dayanağını ülke koşulları ile açıklamaya çalışarak öğretmen adayının, mesleki davranışlarını geliştirme noktasındaki sınırlılıklarından söz etmişlerdir:

Öğretmen adaylarına sorumluluğumuz, duygusal-hissi bir sorumluluktur. Ülkemizin gerçekleri bizim bu sorumluluğu üstlenmemizi sağlıyor. Onların sınıf içi davranışları, okul kurallarına, giyim-kuşam, zamana dikkat etmelerine katkımız oluyor. Fakat onların öğretmenlik becerilerine olan katkımız konusunda bir şey söyleyemeyiz çünkü onları gözlemleme şansımız yok.

Farklı bir ilin uygulama öğretmenleri (G2 ve G3’ten 10 öğretmen), okuldaki eğitsel yükleri, süreçteki sorumluluklarını bilememekten kaynaklanan sorunlar ve tatmin etmeyen uygulama öğretmenliği ücreti söz konusu iken, öğretmen aydının sorumluluğunun sadece manevi doyum ile açıklanabileceğine ilişkin sözleri aşağıdaki şekilde yer almıştır:

Bizler eğitim programını yetiştirelim kaygısında olduğumuz için, aday için ne hazırlığımız ne de sorumluluğumuz vardır. Bizim için bu görev sadece manevi bir doyumdur. Bu da her uygulama öğretmenin de aynı düzeyde değildir. Ama öğretmen adayı ile ilgili sorumluluğumuzu önceden bilir ve maddi anlamda tatmin edilirsek uygulama öğretmenliğinin niteliği artabilir.

Profesyonel bir süreç olan öğretmenlik uygulamalarını, kişisel tercihleri doğrultusunda yürüten farklı okuldaki uygulama öğretmenleri (O2'den 4 öğretmen) "vicdanımız doğrultusunda hareket ediyoruz. İleride onların öğrencilerini düşünerek nitelikli öğretmenler olmalarını istiyoruz" demişlerdir. Öğretmen adayı ile "vicdan”ları gereği ilgilendiklerini söyleyen uygulama öğretmenlerinin yine öznel davranıșlarının sonuçlarıyla karșılașılmaktadır. Kișisel bir tercih nedeni olan vicdani sorumlulukla öğretmen adayına ihtiyacı olan rehberliğin yapılması gerektiğini söyleyen uygulama öğretmenlerinin görüşleri şu şekilde yer almıştır (K3'ten 5 öğretmen) "Uygulama öğretmeninin yasal anlamda sorumluluğu olmadığı halde bu sorumluluğu hisseden uygulama öğretmeni olmalıdır. Bu bir niyet, vicdan, özveri ve gönül işidir”. Diğer 
taraftan (B3'ten 6 öğretmen) "Stajyerlerin yetiştirilmesi ile ilgili yasal sorumluluğumuz olmalıdır. Bu bizlerin insafına bırakıldığında yaşananlar ortada..." (D3 ten 3 öğretmen) diyen farklı bir ilin uygulama öğretmenleri ise bu sürecin profesyonel bir yaklaşım içerisinde olması gerektiğini söyleyerek sürece özeleştirel yaklaştıkları görülmektedir. Uygulama öğretmenlerini, söz konusu sorumluluktan bağımsız kılan okul yöneticisinin sözleri (G1) "Adayların sorumsuzluğunun sorumluluğunu vicdanımız gereği biz taşıyoruz" şeklinde olmuş ve asıl sorumluluğun öğretmen adaylarında olması gerektiğini vurgulamıştır.

Yukarıda yer alan ifadelerden, uygulama öğretmenlerinin sürece ilişkin profesyonel ya da teknik anlamda herhangi bir sorumluluklarının olmadığı, sürecin manevi doyumu sağlamak ve vicdanı rahatlatmak amacıyla gerçekleştirildiği anlaşılmaktadır. Bu durum, inisiyatifli ve öznel davranışların her bir uygulama okulu ve öğretmenine göre değişeceğini, bunun sonucunda bir standarda ulaşılamayacağı söylenebilir. Kurumsallaşmış örgütlerin profesyonel davranış örüntülerine sahip oldukları bilgisinden hareket edildiğinde, bu durumun kurum kültürüne uymadığı görülmektedir. Kurumların belirli bir aşama ya da özelliğe ulaşmış sosyal bir düzen ya da bir kalıp oldukları, kurumsallaşmada tekrarlanan eylemlerin, alışkanlıkların topluluklar içerisinde nasıl standart hale geldiğini ya da kuralımsı bir nitelik kazandığı (Jepperson, 1999; DiMaggio ve Powell, 1991'den Akt. Ulukan, 2005) görülmekte iken öğretmenlik uygulamaları sürecinin zit bir durum arz ettiği görülmektedir. Kurumlar bu nitelikleri ile teknik olarak varlıklarını sürdürmektedir. Çünkü zaman içerisinde kurum, davranışlarını standartlaştırmak durumundadır. Bir kurum, yürütmekle sorumlu olduğu görevlerini, standardı olmayan duyuşsal davranışlar yoluyla gerçekleştirdiğinde, karşılaşılan bir durum için verilen tepki, her seferinde zamana, mekana, yaşa, karşılaşılan bireye vb. bir çok değişkene göre farklılık gösterecektir. Böylece bir uygulama öğretmeninin davranışlarının, kişi, zaman ve mekan bakımından bağımsız olduğu ve her seferinde benzer durumlar için farklı davranışlar sergileyebileceği anlaşılmaktadır. Kaldı ki sorumluluk, yetişkin bir insanın yasalara, alışkanlıklara, kurallara ayak uydurabilmesi ve bunlara aykırı davrandığında ise adil bir şekilde cezalandırılması (MEB, 2000) olarak açıklanmakta iken, uygulama okulu koordinatör ve öğretmenlerinin görev ve sorumluluklarından (YÖK, 1998) haberdar olmamaları dikkat çekmektedir.

Sorumluluk Almayı Sağlayan Koşullar (Birinci Alt Problemin Sonda Sorusundan Elde Edilen Temalar):

Yukarıda yer alan ifadelerden uygulama öğretmenlerinin, öğretmen adayının yetiştirilme sürecinin önemli bir kesitinde yer alıyor olmasına rağmen, sorumluluk alma noktasında kendilerini sürecin dışında tuttukları gözlenmektedir. Bu nedenle "Hangi koşullarda ögretmen adayına iliş̧kin sorumluluğunuz olduğunu düşünürsünüz?” sorusu, sonda olarak kullanılmış ve araştırmanın katılımcıları, öğretmenlik uygulamalarında yer alan değişkenlerin muğlak durumlarını devam ettirdiği sürece, uygulama öğretmenliğine ilişkin herhangi bir sorumluluklarının olmayacağını söylemişleridir. Ancak uygulama öğretmenlerine, mentörlüğe ilişkin farkındalık eğitimi sağlanır ve öğretmenlik uygulamaları geniş zaman dilimine yayılır ise uygulama öğretmenliği sorumluluğunun alınabileceği söylenmiştir. Verilerden elde edilen farkındalık eğitimi ve geniş zaman dilimi temaları ile ilgili alıntılara, aşağıda yer verilmiştir. Süreçteki belirsizliğin kaynağına işaret eden uygulama öğretmenleri (G1'den 4 öğretmen) "sorumluluk" kavramına ilişkin yükümlenmenin sorumlusu olarak gösterdikleri üniversite ve uygulama okulları hakkındaki söylemleri aşağıdaki şekilde yer almıştır:

Uygulama öğretmeni olarak sorumluluklarımız, görevimiz nedir bilmiyoruz. Bu konuda hiçbir fikrimiz yok Bizden talep edilmediği sürece ne yapacağımızı bilemiyoruz. Sadece yoklama alıyoruz. Çünkü bu konuda ne üniversite ne de okulumuz tarafından bilgilendirilmedik.

Sürece ilişkin sorumluluk bilincinin ancak ilgili kurumlar tarafından farkındalık eğitimi ile kazandırılacağını söyleyen mentörler (B1'den 3öğretmen), beklentilerini şu şekilde dile getirmişlerdir: 
Adaylara ilişkin ne resmi ne de gayri resmi bir sorumluluğumuz olduğu hissettirilmiyor. İdeal koşullar sağlanır ve eğitilirsek eğitim fakülteleri ile kriterler paralel olursa sorumluluğumuz olur diyebiliriz.

Araştırmaya katılan uygulama öğretmenleri (D1'den 7öğretmen) ve okul yöneticilerin çoğunluğu, öğretmen adayı dolayısı ile öğretmenlik uygulamaları sürecinin sorumluluğunu alma koşulunu sağlayan en önemli gerekçeyi, öğretmenlik uygulamaları süresinin daha geniş zaman dilimine yayılması olarak göstermiş̧lerdir:

Öğretmen adayının ancak altı aylık bir staj süreci için sorumluluk payımız \%70-80 dir diyebiliriz. Şu anki uygulamada \%10 bile denilemez şahsi etkimiz olduğu düşünüldüğünde.

Yine sorumluluğun staj süresi ile ilgili olduğu görüşünü savunan farklı bir ilin uygulama öğretmenlerinin (K2'den 4öğretmen) ortak önerileri, diğer öğretmen ve yöneticilerin önerileri ile paralellik göstermektedir "...böylece, aday bir yıl süresince uygulama öğretmeninin asistanı olursa ve tek elden tüm dersleri bizde gözlemlerse adayın sorumluluğu da bizde olur" demişlerdir. Görüşme yapılan farklı bir grubun (K3'ten 3öğretmen) mentörleri, sorgulayıcı bir yaklaşımla yöneltilen soruya soru ile yanıt vermişlerdir “..haftada bir gün 40-80 dakikada bizimle olan aday ile ilgili sorumluluğumuz sizce nasıl olmalıdır?". Aynı okulun uygulamadan sorumlu müdür yardımcısı (K3) "Bence öğretmen adaylarının yetiştirilme sorumluluğu \%80 dir, fakat staj süresi uzun olduğu takdirde" diyerek uygulama öğretmenleri aynı görüşte oldukları anlaşılmaktadır. Eğitim olanakları bakımından daha iyi koşullarda olan bir ilimizin merkezinde yer alan uygulama okulu müdür yardımcısı(O1), yukarıda yer alan görüşlere evrensel bir boyut ekleyerek "Adayın yetiştirilmesinde uygulama öğretmeninin sorumluluğu evrensel olmalıdır. Yarım dönemlik stajla uygulama öğretmenlerinin sorumluluğu çok azdır” demiştir.

Araştırmadan elde edilen veriler, öğretmenlik uygulaması süresinin uzatılmasına bağlı olarak sorumluluk bilincinin de artacağını göstermektedir. Nitekim Gökçe ve Demirhan'ın (2005a) uygulama öğretmenleri ile gerçekleștirdikleri bir araştırmada, uygulama süresinin daha uzun olması gerektiğine ilișkin sonuç elde edilmiș olması bu konunun detaylı olarak ele alınması gerektiğini düşündürmektedir. Çünkü araştırmanın verilerinden, uygulamalar için ayrılan kısa zaman diliminin "emek vermeğe değer" duygusundan yoksun bıraktığı anlaşılmaktadır.

\section{2 İkinci Alt Probleme İlișkin Bulgular: Uygulama Öğretmeninin Görev ve Rolleri}

\section{Görev ve Roller (Üst Tema):}

Araştırmanın katılımcılarından, uygulama öğretmeninin görevinin "akademik yeterliliğini" sağlamak, rolünün ise "iletişim" becerisinin olması gerektiği ile ilgili temalar elde edilmiştir.

\section{Akademik Yeterlilik Görevi (Tema):}

Araştırmanın katılımcıları, bir uygulama öğretmeninin görevinin akademik yeterliliğini sağlamak olduğunu söylemişlerdir. Bu görevi yerine getirebilmesinde farklı yeterlilik alanlarının gerektiğini söyleyen uygulama öğretmenleri (B1'den 5 öğretmen), akademik yeterlilik kapsamında ele aldıkları değişkenler şu şekilde ifade etmişlerdir:

Bilgi birikimi olmalı, sınıfını bir laboratuar gibi hazırlamalı, adayın planlarını birlikte yapmalı, sınıf düzenin sağlamalı, öğrencilerin gelişim dönemleri hakkında adayları bilgilendirmeli, uygulama öğretmeninin uygulamaları ile söyledikleri arasında uyum olmalıdır.

Yine farklı bir okulun uygulama öğretmenleri (B3'ten 5öğretmen), akademik yeterlilik kapsamındaki nitelikleri, öğretmen adayına örnek olunması bakımından ele almışlardır:

Derslerine zamanında girip çıkmalıdır, sınıf yönetimi tam olmalıdır, öğretim yöntem ve tekniklerini iyi kullanmalıdır, alan hakimiyeti olmalıdır, velileri ve öğrencileri ile iyi iletişim kurmalıdır

Uygulama okulu yöneticilerinden biri (K1) “..örneğin, gözlemlenmekten rahatsız olmayan bir öğretmen iyi bir uygulama öğretmeni olabilir. Çünkü kendisini her konuda yeterli hisseden bir öğretmen rahatsız olmaz”, farklı bir yönetici (K3), “.. lider olmalı, yönlendirici ve rehber olmalı ve fakülte ile direk iletişim kurmalıdır" diyerek akademik yeterliğin özgüvene olan 
yansımasına dikkat çekmişlerdir. Farklı bir il ve okul yöneticisi ise (G1) "yönlendirici, destekleyici, yol gösterici ve olumlu model olması gerekir", diyerek uygulama öğretmeninin akademik yeterlilik alanlarından biri olan rehberlik rolünü ön plana çıkarmıştır. Kapsamlı bir akademik yeterlik yelpazesi sunan uygulama öğretmenlerinin (G1'den 4 öğretmen) bu konudaki görüşleri evrensel nitelikte olan uygulama öğretmenliği yeterlik alanlarını kapsayacak nitelikte olmuştur:

\footnotetext{
Bir uygulama öğretmeninin, bilgi donanımı olmalı, kitabi bilgiler dıșına çıkabilmeli, sınıf yönetimi becerisi olmalı, kendini dinletmesinin yollarını bilmeli, zaman yönetimi iyi olmalı, mesleki yeterliliği olmalı, beden dilini iy kullanabilmeli, ses tonu etkili olmalı, motivasyonu sağlayabilmeli, öğrettiklerini somutlaştırabilmeli, geribildirimleri etkili olmalıdır.
}

Ön koşul öğrenmelere bağlı olarak geliştirilecek olan görev listesinde yer alan konuları saptayan uygulama öğretmenleri (B3’ten, 5 öğretmen) “Öğrenme ve öğretme sürecine ilişkin tüm kavram ve yaklaşımları bilmelidir. Adaylar geldiğinde neler yapmamız gerektiğini bilmeliyiz" demektedirler.

Öğretmenlik uygulamaları ile ilgili yapılan çalışmalardan elde edilen sonuçlar, uygulama öğretmenlerinin görev ve rolleri ile ilgili problemlere de işaret etmiştir (Gökçe ve Demirhan, 2005; Can, 2001; Çepni,1999). Bu araştırma ile sözü edilen görev ve rol karmaşasının giderilebileceği düşünülmektedir. Çünkü uygulama öğretmenleri rolümüz iletişim, görevimiz ise akademik yeterliliğimizi sağlamaktır şeklindeki görüşleri, tarafların üzerlerine düşenleri bilmesi bakımından önemlidir. Çünkü hem uygulama öğretmeni hem de öğretmen adayının iletişim süreçleri başlamadan önce her iki tarafın da görev ve sorumlulukları hakkında bilgilendirilmeleri oldukça önemlidir (Broom, 1996). Tarafların nerede ne yapacakları hakkındaki bilgileri sürece dair güven duygusu oluşumunu sağlayacak bu güven duygusu da karş1lıklı ilişkilere olumlu yansıyacaktır. Uygulama öğretmeni- öğretmen adayı arasında kurulan ilişkinin evrimsel olduğu gerçeği göz önünde bulundurulduğunda, sözü edilen güven temelinin önemi ortaya çıkmaktadır. Çünkü öğretmen adayının performansı, uygulama öğretmeninin rehberliği ve desteği sayesinde yeni bir kapasiteye ulaşır ve adayın görüş, düşünüş ve bakış açısı sürekli değişim gösterir.

\section{İletişim Rolü (Tema):}

Uygulama öğretmenlerinin iletişim rolünü yerine getirebilmeleri için, öncelikle uygulama öğretmenliği sorumluluğunu üstlenme konusunda istekli olunması gerektiğinin altını çizen uygulama öğretmenleri (B1'den 3öğretmen) bu konudaki görüşlerini şu şekilde ifade etmişlerdir:

Bu bir gönül işidir. Gönüllü olunduğunda, bu işin bir angaryası mutlaka vardır ve katlanılır. Uygulama öğretmeni işini seven ve yardımseverdir. Böyle olursa öğretmen adayını da kabul eder.

Yine yukarıda yer alan yoruma paralel bir görüşü dile getiren farklı bir ilin uygulama öğretmenleri (O2'den,4öğretmen), özellikle yetişkin öğrenmesi sürecindeki ilişkin yönüne dikkat çekmişlerdir:

Sabırlı ve hoşgörülü olmalıdır. Öğretmen adayını meslektaş olarak görmelidir. Usta çırak ilişkisi olmamalıdır, çünkü usta çok şey bildiğini, çırağın da bir şey bilmediğini kabul eder ve bu süreç etkili olmaz.

Profesyonel bir yaklaşımı içeren yukarıdaki görüşlere ek söylemler sağlayan faklı bir ilin uygulama okulu yöneticisi (B3), "Bir uygulama ögretmeni, bakımlı ve temiz olmasının yanında öğrencilerine aşağılayıcı ve alaycı tavırla davranmamalı, şiveli ve soyut kavramlarla konuşmamalıdır" demiştir. "İnsani ilişkileri yeterli olmalı, bireye değer vermeli, sabırlı olmalı, yetişkin eğitimi konusunda yetkin olmalıdır" diyen farklı bir ilin uygulama okulu yöneticisi (D1) uygulama öğretmeninin iletişim rolünü ön plana çıkarmıştır. Yine okul yöneticilerinden biri (K2) "...öğretmen adayını sahiplenmeli, ona meslektaşı, annesi, ablası-abisi, dostu, arkadaşı olmalı, kişilik gelişimine katkısı olmalıdır" diyerek iki yetişkin arasındaki ilişkinin hangi yönde olması gerektiğine dair görüş belirtmiştir. Farklı bir ilin uygulama öğretmenlerinin (D2'den 4öğretmen) 
iletişim konusundaki vurgulamaları ise uygulama öğretmeninin teknik donanımıyla ilgili olmuştur:

Bizler öğretmen adayına sınıf içi süreçleri nasıl gözlemleyeceği konusunda farkındalık yaratmalıyız, bireysel eğitimin (öğrenci farklılığına göre) nasıl gerçekleştiğini görmelerini sağlamalıyız, baskıcı olmamalı, moral ve motivasyonlarını geliştirmeli, özgüven ve mesleki gelişimlerini sağlayarak aynı zamanda kişisel gelişimine de katkı sağlamış olmalıyız.

\section{3 Üçüncü Alt Probleme İlişkin Bulgular: Uygulama Öğretmenliğine İlişkin Eğitim İhtiyac1}

\section{Ĕgitim İhtiyacı (Üst tema):}

Araştırmanın katılımcıları, öğretmen adayına ilişkin sorumluluk alınmasını ve buna bağlı olarak görev ve rollerinin belirlenebilmesi için öncelikle mentörlük ile ilgili hizmet içi eğitim almaları gerektiğine inanmaktadırlar. Katılımcıların, eğitim ihtiyacı konusundaki düşüncelerine aşağıda yer verilmiştir.

Ülkenin doğu kesiminde yer alan ilkokulun müdürü (D1), "Bu bir iştir. Bu işin eğitimi olmadan olmuyor. Yönetici olarak bizim de staj konusunda, sorumluluğumuzun ne olduğunu açıkça bilmemiz lazım" diyerek, mentörlügü profesyonel bir yaklaşım ile betimlemiştir. Başka bir ilin okul yöneticisi ise “..elimizde açık bir mevzuat yok. Uygulama öğretmenlerini nasıl yönlendireceğimizi bilmiyoruz, bunun için eğitim fakülteleri içi dolu kurslar düzenlemelidir" demiştir. Yine ülkenin kuzey bölgesinde yer alan uygulama öğretmenleri (K3'ten 7 öğretmen) ise "Yaptığımız işler el yordamıyla oluyor. Öğretmen adayı için neyi, nasıl, ne ile yapacağımızı öğreten bir eğitim programına ihtiyacımız var. Biz çocuğu eğitmeyi biliriz, yetişkin insan nasıl eğitilir bilmemiz gerekir" diyerek, yetişkin eğitiminin, çocuk eğitimi süreçlerinden farklı olduğunu ortaya koyarak, öğretmen adayı ile olan etkileşimlerinin bir eğitim aracılığı ile daha etkili olacağı çıkarımında bulunulabilmektedir. Farklı bir bölge ve ilin öğretmenleri (O1'den 8 mentör), eğitim fakültelerinin öğretmenlik uygulamaları seminerine yönelik olumsuz eleştirileri aşağıda yer almıştır:

Eğitim fakültesinin bir gün içerisinde, staj ile ilgili verdiği seminer hiçbir işe yaramıyor. Orada söyledikleri ile okulda yaşanılanlar birbiri ile uyuşmuyor. Bize kullanacağımız bilgi ve materyaller veren bir eğitme ihtiyacimız var.

Uygulama öğretmenleri ve okul yöneticilerine, ilgili alt problemin açılımını sağlayan "Eğitim ihtiyacı varsa bu eğitimin içeriği nasıl olmalıdır?", "Eğitimin süreci hakkındaki düşünceleriniz nelerdir?" şeklinde sonda sorular yöneltilmiştir. Elde edilen bulgular, uygulama öğretmenlerinin, uygulama öğretmenliği konusunda bir eğitim gereksinimi içinde olduklarını göstermiștir. $\mathrm{Bu}$ eğitimin, "akademik yeterliliği" sağlayarak "aktif öğrenme" yaklașımı içerisinde gerçekleştirilmesi gerektiği anlaşılmaktadır. Ayrıca talep edilen eğitim sürecinde yoğunlukla "iletişim" becerilerinin geliştirilmesini talep ederken bu "eğitim süresi"nin de en az 15 gün olması gerektiğine ilişkin bulgulara ulaşılmıştır.

Akademik Yeterlilik, Eğitim Süresi ve İletişim (Üç tema, katılımcıların aynı söylemleri kapsamında ele alınmıştır):

Araştırmanın üçüncü alt probleminden elde edilen "akademik yeterlilik" bulgusu, aynı zamanda araştırmanın ikinci alt probleminden elde edilen uygulama öğretmenlerinin görevleri ile örtüşmektedir. Araştırmanın katılımcıları, ikinci alt problemde, bir uygulama öğretmeninin görevinin "akademik yeterliliğini" sağlamak olduğunu söylemişlerdir. Böylece elde edilen bulguların birbirini sağladığı görülmektedir.

Araştırmanın üçüncü alt probleminden, uygulama öğretmenliği eğitiminin gerçekleştirilmesi ve bu kapsamda uygulama öğretmenlerine akademik yeterlilik kazandırılması gerektiğine ilişkin bulgular elde edilmiştir. Sözü edilen bulguları destekleyen katılımcı görüşlerinden birisi, öğretmen adayının sorumluluğunu almak için farkındalık eğitimi verilmesi 
durumunda kaygılarının azalacağını söyleyerek, uygulama öğretmenliğinin tek başına bağımsız bir meslek olmaması gerektiğini de belirten söylemleri (D2'den 4öğretmen) ve akademik eğitimin içeriği hakkındaki talepleri şu şekilde ifade edilmiştir:

\begin{abstract}
Bir eğitime ihtiyacımız var, çünkü bürokratik sorumluluklarımız, görevlerimiz ve rolümüzün neler olduğu söylenmelidir. Sertifika programı ile yetiştirilebiliriz. Ayrıca, uygulama öğretmenliği de kendi başına bir meslek olmamalıdır, böylece kendi mesleğinden ayrılmış olur. Böyle bir programın içeriğinde; yetişkin eğitimi, ÖYT, pratik planlama bilgisi, danışmanlık, gözlem ve değerlendirme olmalıdır.
\end{abstract}

Farklı bir ilin uygulama öğretmenlerinin (O1'den 5öğretmen) talep ettiği eğitim programının içeriğinde yer alması istenilen konular aşağıdaki şekilde ifade edilmiştir:

\begin{abstract}
Yetişkin ile iletişim, etik davranışlar, öğretim yöntem ve teknikleri, gelişim-öğrenme psikolojisi, ölçmedeğerlendirme, karşılıklı bilgi alışverişi (hangi bilgiler nasıl paylaşılacak? Fakülte-okul- uygulama öğretmeni işbirliği), nasıl bir duruş belirlemeliyiz ki adayı sınıfta tedirgin etmeyeyim? Uygulama öğretmeninin görev ve sorumlulukları konularını kapsamalıdır.
\end{abstract}

Okul yöneticileri genellikle uygulama öğretmenlerinin, uygulama öğretmenliğine yönelik akademik anlamdaki eğitim gereksinimlerini, yine öğretim ilke, yöntem ve teknikleri, sınıf yönetimi, teknoloji kullanımı, öğretim yaklaşımları, vb. başlıkları sıralayarak meslek yeterliliği odaklı bir uygulama öğretmeni eğitim programı içeriği önermişlerdir. Bu önerilerde eğitiminin süresi ve iletişim hakkındaki düşüncelerini dile getirmişlerdir. Bu ifadelerden birinin sahibi olan okul müdürü $(\mathrm{O} 2)$, sürece okul yöneticilerini de katarak "Gönüllü olunması koşuluyla iyi bir program ile üniversitelerde eğitilebiliriz. Etkili bir program maksimum 15 gün olmalı ve ilkokulların seminer dönemlerinde olmalıdır" demiştir. Başka bir okulun müdür yardımcısının (B3), akademik yeterliğin sağlanmasında önemli gördügü yetişkin eğitimi ilkeleri ve süreye yönelik önerisi şu şekilde ifade edilmiştir:

Uygulama öğretmenleri kesinlikle eğitim almalıdır. Bu eğitimde, iletişim becerileri, stajyere nasıl davranılması gerektiği, adayların değerlendirilmesi vb. konular olmalıdır. Bu eğitim süresi en az 15 gün olmalıdır.

Faklı bir bölge ve ildeki uygulama okulu müdür yardımcıs1 (D2), diğer katılımcıların da ifade ettiği aynı süreyi içeren ve benzer eğitim içeriği talebini ifade eden bütüncül yaklaşımıyla, pedagoji ve andragoji eğitim ilkelerinin ayırdında olduğunu da gösteren söylemi şu şekilde yer almıştır:

Bu eğitim en az 15 gün olmalıdır. İçeriğinde öğretmen adayının tüm ihtiyaçlarını karşılayacak konular olmalıdır. İyi bir öğretmen olmak ayrı, yetiştiricilik ayrıdır. Yetişkini eğitmek ile çocuğu eğitmek te ayrı şeylerdir. Bu nedenle yetişkin eğitiminin özellikleri ile iletişim becerileri bilinmelidir.

Uygulama öğretmenleri (K5'ten 3öğretmen) ise yeterlilik alanlarında hissettikleri eksikliklerin yarattığ söylemişlerdir "...yani rehberlik eğitimi almalıyız, çünkü adayın beni sorgulama kaygısı yaşıyorum ama bu eğitimi almış olsam bu kaygıyı yaşamazdık" demişlerdir. Bugüne değin uygulama sürecine ilişkin bir farkındalık eğitimi almayan bir başka bölgenin sosyo-ekonomik açıdan orta düzeyindeki bir semtinde bulunan uygulama okulunun, öğretmenleri bu konudaki sitemli serzenişleri “...bizden beklenenlerin neler olduğu, işleniş süreci ile ilgili en az 15 gün olacak şekilde bilgilendirilmemiz gerekir. Bu tür eğitime ihtiyaç duyduğumuz şimdiye kadarki konuşmalarımızdan anlaşılmıştır herhalde“" şeklinde olmuştur. Benzer ifadelerle, ülkenin ulaşılan bütün kesimlerinde karşılaşılmıştır.Yine farklı bir ilin periferinde bulunan uygulama okulu müdürünün (B5), birçok değişkeni ele alan iletişim ile ilgili saptamaları ve eğitim eksikliğinin doğurduğu sonuç ve buna bağlı olarak dile getirdiği eğitim talebi şu şekilde olmuştur:

Aslında fakültelerin bizleri uygulama süreci ile bilgilendirmeleri ve bizimle sıkı ilişkiler içinde olmaları gerekir. Bu konudaki taleplerimiz kabul görmüyor. Hâlbuki paydaşlarla iletişim kurulduğunda memnuniyet sağlanabilir. Şimdiye kadar uygulama ile ilgili hiçbir seminer düzenlenmedi. Bu nedenle uygulama öğretmenlerinin de adaylara etkili bir rehberlik yaptıklarını hiç düşünmüyorum.

Yine farklı bir okul müdürünün (G3) diğer yöneticilerin iletişim sürecine ilişkin görüşlerine paralel olan, "Öğretmenlerin gençlerle nasıl iletişim kurabileceklerini öğreten bir hizmet içi eğitim gerekir" şeklindeki sözleri, kendi hedef kitlelerinin çocuk, öğretmen adayının 
ise yetişkin olmasına bağlanabilir. Öğretmen adaylarının yetiştirilmesinde en az eğitim fakülteleri kadar sorumlulukları olduğuna ve iletişimin önemine vurgu yapan okul müdürünün (K2), bu konudaki ifadeleri aşağıdaki şekilde yer almıştır:

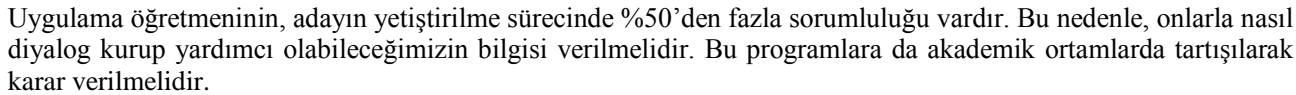

Uygulama öğretmeninin, adayın yetiştirilme sürecinde \%50'den fazla sorumluluğu vardır. Bu nedenle, onlarla nasıl diyalog kurup yardımcı olabileceğimizin bilgisi verilmelidir. Bu programlara da akademik ortamlarda tartışılarak karar verilmelidir.

Yukarıda yer alan "iletişim" teması bulgusu, yine araştırmanın ikinci alt probleminin bulgusu olan ve uygulama öğretmeninin rolü, "iletişim" olmalıdır ile örtüşmektedir. Böylece, uygulama öğretmeni ve öğretmen adayı arasında kurulacak "ilişki”, öğretmenlik uygulamalarının niteliğini belirlemesi açısından oldukça önemli görülmektedir.

\section{Aktif Öğrenme (Tema):}

Uygulama öğretmenliğine ilişkin eğitim ihtiyacında olduklarını söyleyen katılımcılar, yüksek lisans program beklentilerinin yanında daha çok aktif ögrenmeye dayalı bir süreç beklentisi içerisinde olduklarını belirterek (O1'den 5 öğretmen) "Bize bu konuda ne yapacağımızı bilmemiz için bir hizmet içi eğitim ya da yüksek lisans programı açılabilir. Ama bu eğitimler mutlaka pratiğe yönelik olmalıdır" demişlerdir. Katılımcıların kendilerine sağlanacak olası bir eğitim sürecinde, aktif olmak istediklerini betimleyen söylemleri şu şekilde gerçekleşmiştir: B2'den 2 öğretmen, ”..iletişim becerileri (birebir ve grup), ölçme değerlendirme, diksiyon, öğretme yaklaşımları, planlama, sınıf yönetimi, seminer dönemlerinde, en az iki hafta günde 4'er saatten özellikle uygulamalı ve sertifikalı olmalıdır" şeklinde ifade ederken, bir başka grup uygulama öğretmeni (D2'den, 6öğretmen) de, "Hizmet içi eğitime ihtiyacımız var. $\mathrm{Bu}$ seminerde, adaylarla iletişim ve yetişkin eğitimi gibi konular da aktif olmalıyız. Böylece bizim mesleki ve kişisel gelişimimize de katkısı olur" demişlerdir. Yine farklı bir gruptaki uygulama öğretmenleri (D3'den, 5öğretmen) taleplerini kısaca "Adayları öğretme ortamına katmanın ve etkin kılmanın yolları önce bize sonra da adaylara öğretilmelidir" diyerek, öğrenme sürecinin nasıl olması gerektiğine ilişkin dikkat çekmişlerdir. Farklı bir il ve okulda görev yapmakta olan uygulama öğretmenlerinin, önceki dönemlerde gerçekleştirilen farkındalık seminerine ilişkin olumsuz yaşantılarını (K2'den,3öğretmen) "Üniversitesinden bir hoca açıklama yapmıştı ama işe yarayan bir şeyden söz etmemişti. Bir günlük sertifikalı eğitimdi. Tamamen teorik olduğu için etkili olmadı ayrıca bu eğitim adaylar okuldan gittikten sonra verildi" şeklinde ifade etmişlerdir.

\section{TARTIŞMA, SONUÇ VE ÖNERILER}

Araştırmanın bulguları bütüncül olarak ele alındığında, mentör ve öğretmen adayı arasında sağlanan etkileşim biçiminin, daha çok geleneksel/kariyer geliştirme modeline (mentörün bilgisi, deneyimleri, ilişkileri ve rehberliğinden yararlanma) göre yapılandırılmak istendiği görülmektedir. Bu tercih, Türkiye de uygulanmakta olan yeterliliğe dayalı öğretmen yetiştirme modeliyle tutarlılık göstermesi bakımından önemli bir sonuçtur. Böylece, geliştirilmesi planlanan olası öğretmen eğitimi programları, mentör yetiştirme programları, öğretmenlik uygulamaları süreci ile ilgili mevzuat ve yönetmeliklerin, bu çalışmadan elde edilen bulgular çerçevesinde yapılandırılabileceği düşünülmektedir.

$\mathrm{Bu}$ çalışma, uygulama öğretmenlerinin görev ve rol kapsamında yer alması gereken değişkenleri belirlemiştir. Araştırma, mentörlerin görevinin akademik yeterliklerinin, rollerinin ise iletişim becerilerinin sağlanması gerektiğini ortaya koymuştur. Sözü edilen değişkenlerin, uygulama sürecini yürütmekle sorumlu olan kişiler tarafindan belirlenmiş olması önemli görülmektedir. Çünkü mentör eğitimi programları ya da yeniden yapılandırılması muhtemel mentör görev, rol ve sorumluluğu açısından bu çalışmayla bir çerçeve oluşturulmuştur. Yine bu araştırma, mentörlerin görev ve rollerinin belirlenmesi durumunda sorumluluklarının da olacağı sonucunu ortaya koyması bakımımdan oldukça önemlidir. Yine bu araştırma ve alan yazında yer alan ilgili araştırmalar, Türkiye de yürütülmekte olan uygulama öğretmenliği sürecinin 
profesyonel bir yaklaşımdan uzak olduğunu göstermektedir. Uygulama öğretmenlerinin, işbirliği yapmas1, programı yürütmesi, rehberlik yapmas1, etkinlikleri izleyerek denetlemesi ve değerlendirmesi ile ilgili üç maddelik "Öğretmenlik Uygulamasına İlişkin Yönerge" (YÖK, 1998; MEB, 2014)'nin günümüz ihtiyaçlarına yanıt vermediği bu araştırmanın sonuçları kapsamında söylenebilmektedir. Çünkü söz konusu yönergede, görev ve roller sınırlı olsa da belirtilmiş fakat bunların nasıl gerçekleştirileceği ifade edilmemiştir. Bu araştırmanın sonucu, öğretmenlik uygulamaları sürecinin tamamen, manevi doyum ve vicdani sorumluluğa dayalı olarak yürütüldüğünü gösteriyor ise, söz konusu yönergenin etkililiği, geçerliliği ya da ihtiyac1 ne kadar karşılıyor olduğunun araştırılması gerekmektedir.

Araştırmanın katılımcıları, öğretmenlik uygulamaları sürecine ilişkin sorumluluklarının olmadığını söylemelerine rağmen, resmi bir mentörlük eğitimi aracılığı ile kazandırılacak olan rol ve görevlerinin sonucunda, sorumluluklarının olabileceği anlaşılmıştır. Böylece, mentörlerin görev ve rollerin açıklanarak netleştirilmiş olması ile öğretmenlik uygulamalarına ilişkin sorumluluk alma arasında sıkı bir ilişkinin olduğu görülmektedir. Sorumluluk için, her şeyden önce yetkin, yetkin olmakla da kendine egemen bir bilinç gerekmektedir (Timuçin, 1997, s:83) bunun için uygulama öğretmenliği farkındalık eğitimi ile önce yetkinlik temelinde bilinç ve bunlara bağlı olarak sorumluluk duygusu kazandırılmalıdır. Böylece öğretmenlik uygulamaları süreci, "duygusal boyuttan", teknik dolayısıyla profesyonel bir boyuta ulaşılmış olacaktır. Nitekim yukarıda sözü edilen mentör eğitimi kurs programı, bu haliyle hem bu çalışmanın ortaya koyduğu bulgulardan hem de ulusal düzeyde gerçekleştirilen bir araştırmanın sonucundan (Yalın Uçar, 2013) da anlaşlacağı üzere, uygulama öğretmenlerine beklenen görev ve rolü kazandırmamaktadır. Ülkenin ulaşılan tüm kesimlerindeki uygulama öğretmenleri ve okul yöneticileri, uygulama öğretmenliğine yönelik bir eğitim programının olması konusunda oldukça istekli görülmektedirler. Hatta ülke genelinde yapılan bir araştırma sonucunda mentörlük konusunda yüksek lisans talebi ile de karşılaşılmıştır (Yalın Uçar, 2008). Bu nedenlerle uygulama öğretmenliği eğitim programları, tanımlanmış bir çerçevede gerçekleştirilmelidir. Bu çalışma, yine öğretmenlik uygulaması süresinin, hâlihazırdaki uygulama süresinden daha uzun olması gerektiğini sonucunu da ortaya koymuştur. Uygulama süresinin sınıllılı̆̆ının, öğretmen adayına ilişkin sorumluluk alma noktasında problem oluşturduğu anlaşılmıştır.

Uygulama öğretmeni eğitim programının, mentörlere akademik yeterlilik ve iletişim becerilerini geliştirmeye yönelik olması ve aktif öğrenme yaklaşımına dayalı olarak en az iki haftalık bir süre içerisinde yürütülmesi gerektiği anlaşılmaktadır. Böylece uygulama öğretmenlerinin, mentörlükle ilgili bilgi sahibi olmalarını sağlayan ve öğretmen adayının, öğretme yeteneğini geliştirmesinde kullanabileceği eğitim programları (Kay, 1990'dan Akt. Iris ve Sandlin, 2002) geliştirilebilir. Çünkü bu araştırmanın bulguları, geliştirilmesi muhtemel bir mentör eğimi programının ihtiyaç analizine götürmektedir. Bu çalışma ile söz konusu eğitim programının yaklaşımı, içeriği, yöntemi ve süresi tespit edilmiştir. Eğitim ihtiyacına yönelik olarak geliştirilen uygulama öğretmeni eğitim programları, uygulama öğretmenlerinin eğitsel ve kişisel gelişimleri ile öğretmen adaylarının akademik ve kişisel gelişimlerine katkı sağlamaktadır (Board of Education of the City of New York, 1994; Ciriza ve Pérez, 2005; Coulon, 2000; Connie ve Diğerleri, 1995; Shantz, 1995; Whitsett ve Riley, 2003; Yalın Uçar, 2008c). Araştırmanın bulguları, uygulama öğretmenlerinin iletişim becerileri ve öğretmenlik mesleği yeterliliğinin iyi olması gerektiği sonucuna götürmektedir. Uygulama öğretmenliği sürecinin karşılıklı nitelikli ilişki temeli üzerine kurulması durumunda sağlanan güven ortamı sonucunda, uygulama öğretmeninin akademik alandaki yeterlikleri ile etkileşim söz konusu olacaktır. Dolayısı ile öğretmen adayının, uygulama öğretmeninin akademik yeterliliğinden yararlanabilmesi için iletişim teması ön koşul olma niteliği taşımaktadır. Böylece etkili rol modelliğinin önü açılarak, profesyonel kimlik ve beceri duygusu geliştirmede öğretmen adayına yardım ettiği gerçeği göz önünde bulundurulduğunda (Kram ve Isabella, 1985'den Akt. Ast, 2002) uygulama öğretmeninin rol modelliğe olan katkısı anlamlı olacaktır. 
Uygulama öğretmenliği sorumluluğu, devlet memurluğu hizmet şartları kapsamında değildir. Uygulama öğretmenliği, kendi ilkokul öğretmenliğinin yanında ek olarak üstlenilen bir sorumluluk olduğu gerçeği göz ardı edilmeden mentörlük görev, rol ve sorumluluk çerçevesinin belirlenerek bu görevin nasıl gerçekleştirileceği açıç̧a belirtilmelidir. Çünkü eğitim fakültelerinin teorik boyutta öğretmen adaylarına kazandırdıkları yeterlikleri gözlemleyebilecekleri ve öğretmen adayının kendisine ilişkin yansıtıcı düşünmesini sağlayan yegane ortam, öğretmenlik uygulamaları sürecidir. Bu sürecin, el yordamı ile sürdürülmesine son verilerek, öğretmen eğitiminin uygulama boyutunu yürütmede anahtar rol oynayan uygulama öğretmenlerinin görev ve rolleri kazandırılarak uygulama sürecine ilişkin sorumluluk almaları sağlanmalıdır. Yüksek Öğretim Kurumu, Milli Eğitim Bakanlığı, Eğitim Fakülteleri ve Uygulama Okullarının nitelikli işbirliği çerçevesinde, öğretmen eğitiminin teorik sürece verdiği önem kadar uygulama boyutuna da gereken önemin verilmesi ile profesyonel bir uygulama sürecinden söz edilebileceği düşünülmektedir.

\section{KAYNAKLAR}

Ast, J. V. (2002). Community college mentoring program mentor-mentee handbook. Iowa State University. N239A, Lagomarcino.

Baltaş, A. (2004). Uyandırıcı e-öğrenme, Kaynak Dergisi, 20, Temmuz-Aralık 2004, http://www.baltasbaltas.com/kaynakdergitum.asp?sayi=20, Erişim tarihi, 03 Nisan 2011.

Baştürk, S. (2010). Uygulama öğretmenlerine göre okul deneyimi grubu dersleri ve öğretmen adayları. Gazi Üniversitesi Türk Eğitim Bilimleri Dergisi, 4, 869-894.

Board Of Education Of The City of New York, (1994). Mentor teacher internship program report. Brooklyn: NY.

Broom, H. (1996). Building professional partnerships: a mentor program for special education teachers. 74.Orlando: FL; April, 1-5.

Can, N. (2001). Öğretmenlik uygulamasının yönetimi ile ilgili yeni düzenlemenin getirdikleri ve yaşanan sorunlar. $E$. Ü. Sosyal Bilimler Enstitüsü Dergisi, Sayı: 11, 239-262.

Ciriza, F; Pérez, R. (2005). Making each new teacher our responsibility end of year report. El Paso, Texas, 19 September.

Coulon, S. C. (2000) The impact of cooperating teachers' task statements on student teachers' pedagoji behaviors. Journal of Education for Teaching, 34 (2), 284.

Çepni, S, Ayas, A.P. ve Baki; A. (1999). Fakülte-okul iş birliği modelinin uygulanmasında karşılaşılabilecek temel sorunlar ve çözüm önerileri. III. Ulusal Fen Bilimleri Eğitimi Sempozyumu Bildiri Kitabı, 1, 74-86.

Connie, B; Others. (1995). Iowa community college induction [microform]: Mentoring (CCIM) program. Paper presented at the Annual International Conference of the National Institute.

Daloz, L. A. (1983). Mentors: teachers who make a difference, in: change. Vol. 15. N.6, 24- 27. http://www.nickols.us/homers_mentor.htm, Retrieved on March 14, 2008.

Fish, D. (1995). Quality mentoring for student teachers a principled approach to practice. David Fulton Publishers Ltd. 2 Barbon Close, London: WCIN 3JX.

Galbraith, M.W.; Cohen, N.H.(1995). Mentoring: new strategies and challenges. New directions for adult and continuing education. San Francisco, CA: Jossey-Bass, Summer, EJ 511, 66.

Glesne, C. (2013). Becoming qualitative researchers-nitel araştırmaya giriş (2.Basım). (Çev. Ali Ersoy; Pelin Yalçınoğlu). Ankara: Anı Yayıncılık.

Gökçe, E.; Demirhan, C. (2005a). Öğretmen adaylarının ve ilköğretim okullarında görev yapan uygulama öğretmenlerinin öğretmenlik uygulaması etkinliklerine ilişkin görüşleri. Ankara Üniversitesi Ĕgitim Bilimleri Fakültesi Dergisi, 38 (1), 43-71.

Gökçe, E.; Demirhan, C. (2005b) Öğretmen eğitiminde yenilikçi bir yaklaşım mı yoksa geleneksel bir anlayış mı?. Ankara Üniversitesi Eğitim Bilimleri Fakültesi Dergisi. 38 (2), 187-195 
Karaca, N.H. ve Aral, N. (2011). Okul öncesi öğretmen adaylarının öğretmenlik uygulamalarında karşılaştıkları sorunlar. 2nd International Conference on New Trends in Education and Their Implications. 27-29 April, Antalya-Turkey.

Krueger, R.A.; Casey, M.A (2000). Focus groups: a practical guide for applied research. 3rd Eddition, thousand Oaks, CA; Sage Publication.

Lentz, E; Allen, T.D. (2007) Reflections on naturally ocurring mentoring relationships. In T. Approach, 159-162. Malden, MA: Blavkwell.

Maynard, T; Furlong, J. (1995). Mentoring student teachers (the growth of prefessional knowledge). London: First published by Roudledge 11 New Fetter Lane, EC4P 4EE.

Milli Eğitim Bakanlığı, (MEB 2000). Öğretmen yeterlikleri. Ankara: Taslak Çalışma. Öğretmen Yetiştirme ve Eğitimi Genel Müdürlügü.

Mills, G. E. (2003). Action research: a guide for the teacher researcher, 2nd ed. Columbus, Ohio: Merrill Prentice Hall

Moir, E; Gless, J. (2004). Quality induction: an investment in teachers. New Teacher Center. http://www.newteachercenter.org/article-CCETQInd.html, Erişim tarihi: 25 Haziran 2010.

Öğretmen Adaylarının Milli Eğitim Bakanlığına Bağlı Eğitim Öğretim Kurumlarında Yapacakları Öğretmenlik Uygulamasına İlişkin Yönerge, Tebliğler Dergisi, Ekim 1998/2493: http://mevzuat.meb.gov.tr/html/102.html, Erişim tarihi: 11 Kasım 2014

Riggs, I. M; Sandlin, R. A. (2002). Professional development of mentors within a beginning teacher induction program: How does the garden (mentors) grow?.Paper Presented At Annual Meeting Of The Educational Research Assocation, New Orleans: LA, April 1-5.

Sazak, N. (2003). Müzik öğretmenliği a.b.d. dördüncü sınıf öğrencilerinin uygulama dersindeki yeterliklere ilișkin kendilerini değerlendirmeleri (a.i.b.ü. örneği). Cumhuriyetimizin 80. Yılında Müzik Sempozyumu, 30-31 Ekim, İnönü Üniversitesi, Malatya, 151-155.

Shantz, D. (1995). Teacher education:Teaching innovation or providing an apprenticeship? Education, Spring, Vol.115, Issue 3, 339-342

Timuçin, A. (1997). Sorumluluk bilinci. Felsefe Dünyası, 23, 15-21.

Ulukan, C. (2005). Girişimcilerin ve profesyonel yöneticilerin kurumsallaşma perspektifi. Anadolu Üniversitesi Sosyal Bilimler Dergisi, Say1: 2, 29-40.

Whitsett, G; Riley, J. (2003). Defining and applying leadership; perceptions of teacher leader candidates. Educational Research Association, Biloxi, Mississippi.

Yalın Uçar, M (2008). Sinıf ögretmenlerinin hizmet öncesi eğitiminde yer alan staj uygulamalarının değerlendirilmesi. Yayınlanmamış araştırma projesi. MEB, EARGED Protokol, 2006/1, 2007.

Yalın Uçar, M. (20013). Uygulama öğretmenlerinin eğitim fakültesi-okul işbirliği kurs programına ilişkin görüşleri. CBÜ Sosyal Bilimler Dergisi. Cilt 11, sayı,2, Ağustos 2013.

Yapıcı, Ş ve Yapıcı M. (2004). Öğretmen adaylarının okul deneyimi I dersine ilişkin görüşleri.

İlköğretim-Online Dergisi, Y11 :3 (2), 54-59.

Yıldırım, A; Şimşek, H. (2005). Sosyal bilimlerde nitel araştırma yöntemleri. Ankara: Seçkin Yayıncılık.

Yıldız, E. (2002). Okul deneyimi I ve okul deneyimi II derslerinin değerlendirilmesi. Yayınlanmış yüksek lisans tezi, Sakarya Üniversitesi Sosyal Bilimler Enstitüsü, Sakarya.

Yüksek Öğretim Kurumu (1998). Fakülte-okul işbirliği. Ankara: YÖK Yayınları.

\section{Extended Abstract}

Mentoring that has recently gained popularity as a strategy to assist pre-service teachers in learning to teach is a complex process which combines interpersonal psychological development, educational development and social functions. In this process, there are possible outcomes of the roles of respect, professionalism and success up to the degree of parameters of reciprocity and consistency. Under those circumstances, this process must be conducted through a professional approach. Mentors, who have a key role in this process should know their duties, rols and responsibilities about mentoring process. Otherwise, 
teachers cannot attain their goals. Therefore, for the benefit of candidate teachers and the mentoring system, it was a necessity to conduct this case study.

This study adopts a qualitative research approach. The research has been designed using a case study with a holistic approach. The data obtained from this case study was not represented by numbers or norms. Descriptions have been used in the interpretation of data. The qualitative data of this study is analyzed by using the descriptive analysis method. As a result of this analysis, three main themes were brought out; 1-Responsibilities of mentors, 2-The duty and roles of mentors, 3- The necessity and requirements of mentor training process. And also three sub themes were brought out; 1 -emotional factors 2-academic adequacy, 3-communication.

This studyconsists of seven cities and provinces of the east, west, north and middle part of the country that are Ankara, Mersin, Aydın, Agri, Sinop, Bolu and Bursa. The group consists of seventy-six mentors and 22 school administrators. Thus, the process of teaching practice through the teachers' submissions were obtained from 100 participants. Mentors and school administrators' professional experiences have changed between eight to twenty-five years. The data were collected by researchers who visited each city. In this study open-ended questions were asked to mentors and school administrators. For example, "what do you think about the duty/ responsibilities or role of candidate teacher when pre-service teacher education?" Their answers were written by researcher at the same time during the interview process. Then, the data were transferred to a word-processor by the researcher. This case study brought out what the mentors' duty, role and responsibilities must be. All mentors' duty, role and responsibilities were determined by mentors and the school administrations. For this reason, all the data and results obtained from this case study are thought to be very important.

This study also shows the ways mentors and school administrations perceive the case, subjects, facts, and behaviors as a whole. Based on this, the duties of the mentors, in addition to their roles and responsibilities were determined. For this reason, the aim of the research is to reveal whether the individual throughout teaching application has a role and responsibilities about teaching applications. As a result, awareness about the process of the participants and a criterion of being a mentor was determined.

The analysis shows that mentoring is mentors' legal duty but as mentors they do not have any legal roles and responsibilities. Unfortunately, this result indicates that mentor teachers are not aware of their duties, role and responsibilities. The data shows that the mentors have no legal responsibilities upon the candidate teachers but mentoring depends on emotional factors. These factors are pre-themed as moral satisfaction and self-conscience. Mentors have been pointed out that they have been mentoring to relieve their self-conscience and to have moral satisfaction. When they have to take legal responsibilities, they would demand to be educated by the mentoring curriculum. These mentoring educational processes should be undertaken in a reasonable time period and teaching practiced process to future teachers should be at least a year. The participants of research mention that at least two weeks active learning process is a must in possible mentoring education.

The participants have pointed out that mentors' role is having a qualified 'communication' with the candidate teachers and his/her duty is ''academic adequacy'. Academic adequacy includes different educational approaches, techniques, strategies, usage of updated technologies and effective classroom management. Based on the results of the study, mentors mentioned that their other role is providing a satisfactory communication between candidate.

This communication role includes empathy, observation, feedback, self-confidence, tolerance and willingness to do mentoring. Since the data of the research was obtained from the administration and mentors of all geographical areas of Turkey, it has a cultural and authentic value. These results can be used as a base for future mentor training curriculum development. 